http://nv.nltu.edu.ua

\title{
ENVIRONMENTAL AND ECONOMIC CHALLENGES OF CLIMATE CHANGE FOR EASTERN EUROPEAN FORESTS IN MID-LATITUDE ZONE
}

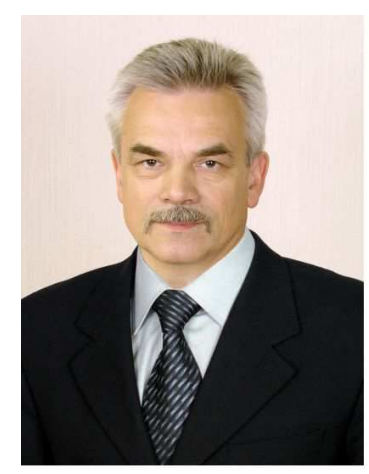

Petro Lakyda, Dr. Hab., Professor, Email: lakyda@nubip.edu.ua

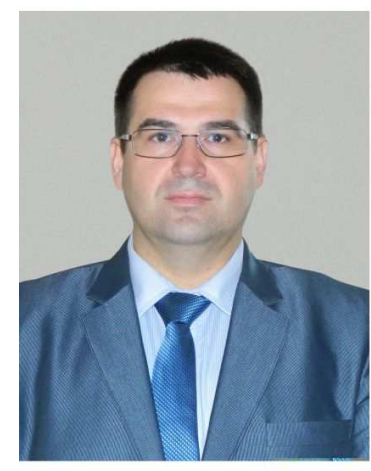

Roman Vasylyshyn, Dr. Hab., Professor,

Email: r.vasylyshyn@nubip.edu.ua Email: ivan.lakyda@nubip.edu.ua

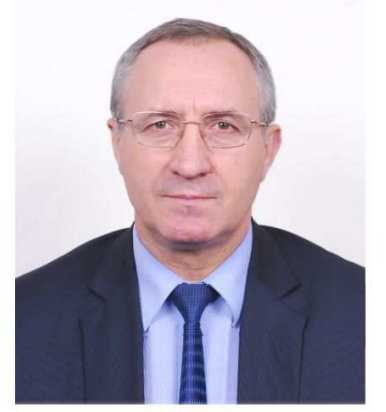

Anatolii Karpuk, Dr. Hab., Professor, Email: karpuk@nubip.edu.ua

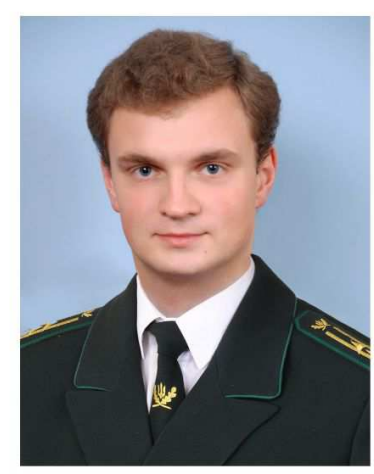

Ivan Lakyda,

PhD, Associate Professor,

The article considers the main challenges facing the forest sector of European part of Mid-Latitude zone in connection with climate change. The main aim was to systematize available scientific information on climate change influence on forests in the research region. The methods of analysis, synthesis, comparison and generalization of available scientific information were applied. Environmental results of climate change impact on forests are represented by future worsening stability and sanitary state of forest stands of Ukraine's main forest-forming tree species. This becomes more and more noticeable for Scots pine dominated stands across Ukraine, and the future for forests composed by other tree species is no longer optimistic in the long run. It is stated that the changing environment will lead to alteration of growth, productivity and bioproductivity of Ukrainian forests, and, consequently,to the necessity to rethink approaches to selection of tree species, forest caring and growing, assessment of ecosystem functions and so on. Economic consequences of climate change for forestry will manifest themselves in the loss of resources, loss of income, as well as expenditures for implementing environmental stabilizing measures. The attention is drawn to significant volumes of normative and information support as well as unique empirical data accumulated in Ukraine during a prolonged period of forest management, forest science and practice. Those are actively used to describe dynamics of various characteristics of forest ecosystems within scientific research, management planning and forest industry. The importance of improving the information support of the forestry sector is emphasized, which will ensure the possibility of forecasting the state of forests under climate change conditions and making sound managerial decisions, and possible pathways for this are highlighted. Characterized are necessary prerequisites and possible ways of transition to the paradigm of sustainable development on the basis of risk-resilient forest management in Ukraine and in geographically greater region.

Keywords: forest; climate change; productivity; ecosystem functions; forecasting; risk-resilient forest management.

\section{Introduction}

Climate change is one of the most serious challenges of today for natural and man-made systems. Their influence on forests, which are one of the most important components of Earth's ecosystem, is nonlinear, difficult to predict at local and regional levels, and requires application of mitigative and adaptive measures today to preserve forest integrity and sustainability in the future. The peculiarity of Eastern-

European part of Mid-Latitude zone is its low forest-land percentage. This is a prerequisite for manifestation of climate change consequences in forest sector and other related fields. The necessity to comply with binding international environmental and climate-protective commitments justifies the application of modern methods and approaches in Ukraine to take into account a response of forest ecosystems to environmental changes, including climate change.

Цитування за ДСтУ: Lakyda P. I., Karpuk A. I., Vasylyshyn R. D., Lakyda I. P. Environmental and economic challenges of climate change for forests of Eastern-European part of mid-latitude zone. Науковий вісник НЛтУ України. 2017. Вип. 27(8). С. 97-100.

Citation APA: Lakyda, P. I., Karpuk, A. I., Vasylyshyn, R. D., \& Lakyda, I. P. (2017). Environmental and economic challenges of climate change for forests of Eastern-European part of mid-latitude zone. Scientific Bulletin of UNFU, 27(8), 97-100. https://doi.org/10.15421/40270815 
The main aim of this research is systematization of climate change influence on forests in the research region. The object of this research is the approaches to formalizing description and forecasting growth and productivity of forests, as well as assessment of their ecosystem functions, taking into account climate change-induced impact. The subject of the studies is the processes of growth of forest stands under climate change conditions.

\section{Material and methods}

In order to achieve the above main aim, the authors have applied the methods of analysis, synthesis, comparison and generalization of available scientific information on climate change impact on forests. The authors used the research results of Ukrainian and foreign scientists as pertaining to growth and bioproductivity of forests, economic evaluation of their ecosystem functions, the role and influence of climate change on formation of forest productivity, modeling and forecasting the state of forest resources under conditions of environmental changes as well as risk-resilient forest management.

\section{Results}

The consequences of climate change for stability and sanitary state of forest stands of Ukraine's main forest-forming tree species are already causing considerable concern. In recent years, particularly, there has been a significant deterioration in sanitary state of pine forests, among the causes of which are outbreaks of pests and forest diseases, as well as extreme climatic phenomena such as droughts and heatwaves. The situation for stands of other forest-forming tree species is no less worrying in the long-term perspective.

The latest research of Ukrainian scientists provides grounds for considering dynamics of ranges of major forestforming tree species. According to the research results, the southern boundary of Scots pine range in Ukraine is expected to move 200-250 km northward (Kolomytcev \& Prydatko, 2017). The comprehensive research carried out within the framework of "Clima East" project indicates a significant deterioration in forest growth conditions on major part of Ukraine's territory by the end of XXI century (Shvidenko, et al., 2017; Climaeast, 2016). The described trends will lead to alteration of growth, productivity and bioproductivity of Ukrainian forests, as well as substantiate the necessity to rethink approaches to selection of tree species, forest caring and growing, assessment of ecosystem functions etc.

In the course of research on impact of climate change on economic growth and development, the focus is on threats to such key elements of human life as access to water, food, changes of health, changes in land use and the environment. A detailed scientific analysis of the influence of climate change on these areas in the context of different degrees of climate change (with a global temperature increase by 1-5 ${ }^{\circ} \mathrm{C}$ and more) indicates large-scale threats (Stern, 2007). For forest sector of Eastern European part of Mid-Latitude zone, a negative economic effect will be reflected in the loss of resources, loss of income, as well as expenditures for implementing environmental stabilizing measures. On the example of Ukraine, an insufficiency or a complete absence of spatially explicit quantitative economic assessments of selected ecosystem functions of forest phytocoenoses should be noted. It is also worth emphasizing possible reduction in economic value of some ecosystem functions of forests due to a decrease in the intensity of their performance due to climate-induced changes in the environment.

During a prolonged period of forest management, forest science and practice in Ukraine have accumulated significant volumes of normative and information support material, which is actively used to describe dynamics of various characteristics of forest ecosystems within the process of scientific and management planning activities (Kashpor \& Strochynsky, 2013; Lakyda, et al., 2013; Lakyda, et al., 2011). A peculiarity of the current situation for forestry is defined by the impossibility of using the existing materials that would characterize growth, productivity and bioproductivity of forests at an adequate level of reliability under the influence of dynamics of climatic system of the Earth and instability of other environmental factors. Accounting for the impact of climate change on the growth and bioproductivity of forests in Ukraine requires implementation of a series of stages on systematization and improvement of the existing regulatory and information support for forestry and its further integration into the existing global or regional models of forest ecosystem dynamics. It is worth noting that a considerable amount of unique material has been collected as a result of the research on growth, productivity and bioproductivity of Ukrainian forests over a significant period of time (Lakyda, et al., 2017; Lakyda, et al., 2016; Schepaschenko, et al., 2017).

In order to improve compatibility of the national information support of forestry with the modern international scientific developments, it is necessary to develop a system of models of growth and productivity of modal (Lakyda \& Vasylyshyn, 2016) and fully stocked stands composed of the main forest-forming tree species of Ukraine, and also to systematize the existing national information support for assessing their bioproductivity using approaches that are internationally recognized in science and practice. Methods and approaches (Shvidenko, et al., 2008). This system shall provide dynamics of the main mensurational indices for stands of major forest-forming tree species of Ukraine in a unified form, using a common type of modeling and mathematical tools and means. Compliance with the above-mentioned principles and approaches will allow for further expansion of those systems and enable development of materials for assessing ecosystem functions of forests on its basis. Currently, Ukraine has an experience in assessing net primary production and carbon budget of forests (Shvidenko, et al., 2014) as well as their energy potentials (Vasylyshyn, 2016).

A necessary prerequisite for practical implementation of deterministic and nondeterministic approaches of risk-resilient forest management is availability of appropriate modeling tools and other information support. Based on these means, by considering the most prospective scenarios in conditions of uncertainty of ecosystems response to changing climatic factors, it becomes possible to determine best suitable mitigative and adaptive forest management options as components of multiple strategies (Millar, Stephenson \& Stephens, 2007). However, these stages are preceded by a considerable amount of work on harmonizing the existing regulatory and information support, involving internationally recognized modelling systems and environments, implementing economic assessment of ecosystem functions, developing national forest policy and many other steps, 
a lack of which results in an inability of transition to the paradigm of sustainable development on the basis of risk-resilient forest management in Ukraine. A successful resolution of the tasks outlined above makes it possible to create a platform for productive interdisciplinary international collaboration of scientists and practitioners from different institutions.

\section{Conclusions}

The impact of global climate change on forests of northern and equatorial parts of the globe is a subject of long-term systematic research, including environmental and economic forecasts. Eastern European part of Middle Latitude zone, which includes forests of flatlands of Ukraine is one of the most potentially vulnerable regions. Given low percentage of forest cover, climate change will be actively reflected on habitat trends of the main forest-forming tree species (Scots pine, European spruce, common oak). These phenomena will be accompanied by dramatic environmental consequences - local forest dieback over large areas. The main reasons for this are weakening of forests by adverse impact of extreme weather events, infestations of diseases and pests, as well as catastrophic forest fires. Negative economic effect will be expressed by loss of resources, loss of income as well as expenditures for implementation of environment stabilizing measures.

All this encourages Ukrainian researchers to conduct consolidated research with European (EFI) and international (IIASA, IUFRO) scientific institutions on developing a system of dynamic models of growth of main forest-forming tree species of Ukraine with account of trends of environmental effects of global climate change and economic forecasts which should be taken into consideration for implementation of risk-resilient forest management.

Ensuring sustainable forest management in a changing world is a complex task, fulfilling which should be based on science and appropriate practical implementation of research results. The current trends in environmental indices, especially climatic, are significantly influencing forest ecosystems. Application of traditional Eastern European approach to the description of dynamics of mensurational parameters of forest stands cannot be regarded as a sufficient condition to obtain reliable estimates of their future state under climate change conditions. Development of a "climatic interface" for the existing models of forests' growth and productivity is a step forward in terms of enhancing possibilities of their application under the current conditions. With respect to the mentioned above, standardization and systematization of the existing models is a crucial precondition.

On the example of Ukrainian forestry sector, the relevance and methodological provisions for improving and adapting the current information support to dynamic environmental conditions are highlighted. Attention is focused on advanced integration capabilities of a unified system of growth and productivity models for stands of main forestforming tree species. Its embedding to regional and global forestry models enables forecasting the state of Ukrainian forests by the middle and end of the 21 st century.

The implementation of the proposed approach will enable adequate assessment of risks associated with forest management under conditions of climate change, contribute to decision-making support and create a platform for inter- disciplinary cooperation between researchers and practitioners in Ukraine and around the world. The experimental and modelling groundwork of the scientific team of the National University of Life and Environmental Sciences of Ukraine in addressing the outlined challenges gives reasons for optimistic expectations regarding implementation of roadmap for sustainable forest management in the region.

\section{References}

Climaeast. (2016). Workshop on vulnerability of Ukraines forests to climate change was held in Kyiv. Retrieved from: http://www.climaeast.eu/news/workshop-vulnerability-kiev-2016 (review date: 17.11.2016).

Kashpor, S. M., \& Strochynsky, A. A. (Resp. for issue). (2013). Forest mensuration reference book. Kyiv: Publishing house "Vinichenko", 496 p.

Kolomytcev, G., \& Prydatko, V. (2017). Scotch pine (Pinus silvestris). ULRMC biotic GIS Group. Retrieved from: http://biomodel.info/ua/species/pinus-silvestris-scotch-pine/ (review date: 23.07.2017).

Lakyda, I. P., \& Vasylyshyn, R. D. (2016). Methodological background for development of a system of growth and productivity models for stands of the main forest forming tree species of Ukraine. Forestry and forest melioration, 129, 3-9.

Lakyda, P. I., Bilous, A. M., Blyshchyk, V. I. et al. (2013). Standards for assessment of aboveground live biomass components of stands of the main forest forming tree species of Ukraine: monograph. Korsun-Shevchenkivsky: FOP V. M. Gavryshenko, 457 p.

Lakyda, P. I., Vasylyshyn, R. D., Blyshchyk, V. I. et al. (2016). Coniferous forest stands in Ukraine: live biomass and experimental data: monograph. Korsun-Shevchenkivsky: FOP V. M. Gavryshenko, $480 \mathrm{p}$.

Lakyda, P. I., Vasylyshyn, R. D., Blyshchyk, V. I. et al. (2017). Broadleaved forest stands of Ukraine: live biomass and experimental data: monograph. Korsun-Shevchenkivsky: FOP V. M. Gavryshenko, 483 p.

Lakyda, P. I., Vasylyshyn, R. D., Lashchenko, A. G. et al. (2011). Standards for assessment of aboveground live biomass components of trees of the main forest forming species of Ukraine. Kyiv: Publishing house "EKO-inform", 192 p.

Millar, C. I., Stephenson, N. L., \& Stephens, S. L. (2007). Climate change and forests of the future: managing in the face of uncertainty. Ecological Applications, 17(8), 2145-2151. https://doi.org/10.1890/06-1715.1

Schepaschenko, D., Shvidenko, A., Usoltsev, V., Lakyda, P., Luo, Y., Vasylyshyn, R., Lakyda, I., Myklush, Y., See, L., McCallum, I., Fritz, S., Kraxner, F., \& Obersteiner, M. (2017). A dataset of forest biomass structure for Eurasia. Scientific Data, Vol. 4, Article No 170070. https://doi.org/10.1038/sdata.2017.70

Shvidenko, A. et al. (2017). Vulnerability of Ukrainian Forests to Climate Change. Sustainability, 9(7), 1152-1158. https://doi.org/10.3390/su9071152

Shvidenko, A. Z., Schepaschenko, D. G., Nilsson, S., \& Buluy, Yu. I. (2008). Tables and models of growth and productivity of forests of major forest forming species of Northern Eurasia. Moscow: Nauka, $886 \mathrm{p}$.

Shvidenko, A. Z., Lakyda, P. I., Schepaschenko, D. G., Vasylyshyn, R. D., \& Marchuk, Yu. M. (2014). Carbon, climate and land-use in Ukraine: forest sector: monograph. Korsun-Shevchenkivsky: FOP V. M. Gavryshenko, 283 p.

Stern, N. (2007). The Economics of Climate Change. The Stern Review. Cambridge University Press. 712 p.

Vasylyshyn, R. D. (2016). Forests of Ukrainian Carpathians: peculiarities of growth, biological and energy productivity. Kyiv: CP "Komprynt", 418 p. 


\section{ЕКОНОМІЧНІ ТА ЕКОЛОГІЧНІ ВИКЛИКИ ЗМІН КЛІМАТУ ДЛЯ ЛІСІВ СХІДНОЄВРОПЕЙСЬКОЇ ЧАСТИНИ СЕРЕДНЬОШИРОТНОЇ ЗОНИ}

Розглянуто основні виклики, які постають перед лісовим сектором східноєвропейської частини середньоширотної зони у зв'язку зі змінами клімату та наслідки для ризикостійкого лісоуправління в регіоні. Зазначено, що наслідки кліматичних змін для стійкості і санітарного стану лісових насаджень основних лісотвірних деревних порід України вже сьогодні викликають істотне занепокоєння і спричиняють значний негативний вплив. Очікується відгук лісових екосистем на зміни умов довкілля у вигляді динаміки ареалів окремих лісотвірних деревних видів. Описано економічні наслідки впливу змін клімату, які виявлятимуться у негативному економічному ефекті через втрати ресурсів, недоотримання прибутку та витрати на реалізацію заходів з екологічної стабілізації довкілля. Відзначено накопичення лісовою наукою та практикою в Україні за тривалий період досліджень та ведення лісового господарства значних обсягів нормативно-інформаційного забезпечення й унікального емпіричного матеріалу, які активно застосовують у здійсненні наукової, проектно-лісовпорядної, а також виробничої діяльності. Наголошено на важливості вдосконалення інформаційного забезпечення лісогосподарської галузі задля забезпечення можливості прогнозування стану лісів за умов кліматичних змін і прийняття обгрунтованих управлінських рішень. Охарактеризовано необхідні передумови та можливі шляхи переходу до парадигми сталого розвитку у лісовому секторі на засадах ризикостійкого управління лісами регіону.

Ключові слова: ліс; зміни клімату; продуктивність; екосистемні функції; прогнозування; ризикостійке лісоуправління.

П. И. Лакида, А. И. Карпук, Р. Д. Василишин, И. П. Лакида

Национальный университет биоресурсов и природопользования Украины, г. Киев, Украина

\section{ЭКОНОМИЧЕСКИЕ И ЭКОЛОГИЧЕСКИЕ ВЫЗОВЫ ИЗМЕНЕНИЙ КЛИМАТА ДЛЯ ЛЕСОВ ВОСТОЧНОЕВРОПЕЙСКОЙ ЧАСТИ СРЕДНЕШИРОТНОЙ ЗОНЫ}

Рассмотрены основные вызовы для лесного сектора восточноевропейской части среднеширотной зоны в связи с изменениями климата и последствия для рискоустойчивого лесоуправления в регионе. Отмечено, что последствия климатических изменений для устойчивости и санитарного состояния лесных насаждений основных лесообразующих древесных пород Украины уже сегодня вызывают существенное беспокойство и оказывают значительное негативное влияние. Ожидается отклик лесных экосистем на изменения условий окружающей среды в виде динамики ареалов отдельных лесообразующих древесных видов. Описаны экономические последствия влияния изменений климата, которые будут проявляться в негативном экономическом эффекте из-за потерь ресурсов, снижения прибыли и затрат на реализацию мероприятий по экологической стабилизации окружающей среды. Отмечено накопление лесной наукой и практикой в Украине за длительный период исследований и ведения лесного хозяйства значительных объемов нормативно-информационного обеспечения и уникального эмпирического материала, которые активно применяются при осуществлении научной, проектно-лесоустроительной, а также производственной деятельности. Подчеркнута важность совершенствования информационного обеспечения лесохозяйственной отрасли для обеспечения возможности прогнозирования состояния лесов в условиях климатических изменений и принятия обоснованных управленческих решений. Охарактеризованы необходимые предпосылки и возможные пути перехода к парадигме устойчивого развития в лесном секторе на основе рискоустойчивого управления лесами региона.

Ключевые слова: лес; изменения климата; продуктивность; экосистемные функции; прогнозирование; рискоустойчивое лесоуправление. 